ISSN 2338-1523

E-ISSN 2541-576X

Volume 6 No. 1

Mei 2018

\title{
ANALISIS DAN PERANCANGAN DECISION SUPPORT SYSTEM MENENTUKAN ANGKAT KREDIT DENGAN METODE SAW (SIMPLE ADDITIVE WEIGHTING) PADA LEASING OTO FINANCE BATAM
}

\author{
Ferdinand Mochammad Fachleffi Syarief ${ }^{1)}$, Sandy Suwandana ${ }^{2)}$ \\ ${ }^{1} e$-mail: ferdinand_moch@yahoo.co.id \\ Program Studi Sistem Informasi, STMIK GICI \\ ${ }^{2}$ e-mail: suwandanas@gmail.com \\ Program Studi Sistem Informasi, STMIK GICI
}

\begin{abstract}
ABSTRAK
Salah satu kendala perusahaan leasing adalah masalah kredit macet. Perusahaan leasing merekrut tenaga kerja di bagian Credit Analyst yang bertugas menganalisis kemampuan membayar pemohon kredit dan melakukan survey lapangan agar dapat mengurangi resiko kredit macet. Seorang Credit Analyst diharapkan untuk bekerja cepat dan teliti dikarenakan banyaknya data pemohon kredit yang masuk sehingga tidak menutup kemungkinan terjadi kesalahan misalnya kesalahan perhitungan atau salah dalam membaca data. Sehingga diperlukan model sistem berbasis komputer yang dapat memberikan kemudahan dalam melakukan analisis data, perhitungan penilaian kriteria pemohon kredit. Sistem dirancang dengan menggunakan metode Simple Additive Weighting (SAW) yang merupakan salah satu metode Fuzzy Multiple Attribute Decission Making (FMADM). Metode SAW dipilih karena perhitungan pembobotan kriteria yang tidak terlalu rumit. Sistem yang dibangun diharapkan dapat membantu kerja perusahaan leasing khususnya pada bagian Credit Analyst dalam melakukan penyeleksian pemohon kredit dan dapat mempercepat proses penyeleksian pemohon kredit serta dapat mengurangi kesalahan dalam menentukan konsumen layak kredit.
\end{abstract}

Kata Kunci : Angkat Kredit, Sistem Informasi, Simple Additive Weighting

\section{PENDAHULUAN}

Banyaknya pemohon kredit yang mengajukan kredit dengan kondisi ekonomi yang berbeda-beda menuntut kejelian Credit Analyst dalam pengambilan keputusan. Dalam menentukan konsumen layak kredit, seorang Credit Analyst memperhatikan beberapa prinsip faktor-faktor yang ada. Adapun faktor-faktor yang dijadikan acuan dalam pengambilan keputusan oleh bagian

JURSIMA

Jurnal Sistem Informasi dan Manajemen
Credit Analyst, yaitu kepribadian pemohon kredit, kemampuan membayar pemohon kredit dan kondisi ekonomi pemohon kredit. Dapat disimpulkan bahwa kasus kredit macet yang menyebabkan berkurangnya profit perusahaan Leasing dapat diminimalisir tergantung dari kinerja Credit Analyst dalam proses menentukan konsumen kredit.

Dalam upaya membantu Credit Analyst dalam kegiatan pengambilan keputusan

https://ejournal.giciku.ac.id/

STMIK GICI 
konsumen layak kredit diperlukan sebuah model Decision Support Sytem berbasis komputer yang dapat memberikan kemudahan dalam melakukan analisis data, perhitungan penilaian kriteria pemohon kredit sesuai faktor-faktor terkait, serta membantu pengolahan data pemohon kredit menjadi informasi untuk mengambil keputusan dari masalah semi terstruktur yang terjadi. Sesuai dengan namanya tujuan dari sistem ini adalah sebagai "information Sources" yang dapat digunakan sebagai bahan pertimbangan dalam pengambilan keputusan atau kebijakan tertentu dan merupakan satu model yang fleksibel yang memungkinkan pribadi ataupun kelompok untuk membentuk gagasan dan membatasi masalah dengan membuat asumsi dan menghasilkan pemecahan masalah sesuai yang dibutuhkan.

\section{LANDASAN TEORI}

\section{Sistem Pendukung Keputusan}

Sistem adalah sekumpulan komponen ataupun elemen yang berkaitan dan saling bekerjasama antara satu dengan yang lainnya untuk mencapai sebuah tujuan. Sistem dapat juga diartikan sebagai kumpulan prosedur-prosedur atau sub-sub sistem yang saling terhubung dalam suatu kesatuan dan dirancang untuk mencapai suatu tujuan tertentu.

Menurut Romney dan Steinbart (2015:3), sistem adalah suatu rangkaian yang terdiri dari dua atau lebih komponen yang saling berhubungan dan saling berinteraksi satu sama lain untuk mencapai tujuan dimana sistem biasa nya terbagi dalam sub sistem yang lebih kecil yang mendukung sistem yang lebih besar. Menurut Jogiyanto (2009:1) dalam bukunya

\section{JURSIMA}

Jurnal Sistem Informasi dan Manajemen yang berjudul analisis dan desain mengemukakan definisi sistem adalah suatu jaringan kerja dari prosedur-prosedur yang saling berhubungan, berkumpul bersamasama untuk melakukan suatu kegiatan atau untuk menyelesaikan suatu sasaran yang tertentu.

Keputusan merupakan sebuah tindakan yang diambil dalam memilih satu atau lebih dari berbagai pilihan alternatif yang tersedia yang dipilih berdasarkan kriteria dan alasan tertentu guna menyelesaikan suatu permasalahan. Menurut Vercellis (2009:24) Keputusan merupakan suatu pilihan dari berbagai macam alternatif yang diambil berdasarkan kriteria dan alasan yang rasional. Proses pengambilan keputusan sering disebut juga sebagai penyelesaian suatu masalah.

Sistem pendukung keputusan merupakan sistem yang mampu memberikan penilaian terhadap alternatif guna untuk membantu para manajer dalam pengambilan keputusan. Suatu sistem interaktif yang mendukung keputusan dalam proses pengambilan keputusan melalui alternatifalternatif yang diperoleh dari hasil pengolahan data, informasi dan rancangan model. Menurut Turban dan Aronson (2011:75), Decision Support System (DSS) atau Sistem Pendukung Keputusan (SPK) adalah sistem yang dimaksudkan untuk mendukung pembuat keputusan manajerial dalam situasi keputusan semiterstruktur dan terstruktur. SPK berfungsi sebagai tambahan atau pendukung bagi pembuat keputusan, dapat memperluas pengetahuan dan kemungkinan, namun tidak menggantikan penilaian. Sistem ini ditujukan untuk keputusan yang membutuhkan penilaian dan keputusan yang dapat diolah dengan algoritma atau secara teknis.

https://ejournal.giciku.ac.id/ STMIK GICI 
ISSN 2338-1523

E-ISSN 2541-576X

Volume 6 No. 1

Mei 2018

Fuzzy Multiple Attribute Decision Making (FMADM)

Fuzzy berarti kabur atau samar-samar atau dapat diartikan sebagai suatu nilai yang dapat bernilai benar atau salah secara bersamaan. Dalam fuzzy dikenal derajat keanggotaan yang memiliki rentang nilai antara 0 (nol) hingga 1(satu). Semakin mendekati nilai 1 (satu) maka akan semakin pasti dan sebaliknya. Hal ini berbeda dengan himpunan tegas yang hanya memiliki nilai 1 yang berarti "ya" dan 0 yang berarti "tidak".

Inti dari FMADM adalah menentukan nilai bobot untuk setiap atribut, kemudian dilanjutkan dengan proses perangkingan yang menyeleksi alternatif yang sudah diberikan. MADM (Multiple Attribute Decision Making) itu sendiri merupakan suatu metode yang digunakan untuk mencari alternatif optimal dari sejumlah alternatif dengan kriteria tertentu. Adapun algoritma dari FMADM adalah sebagai berikut:

1. Memberikan nilai setiap alternatif (Ai) pada setiap kriteria (Cj) yang sudah ditentukan, di mana nilai tersebut di peroleh berdasarkan nilai crisp; $\mathrm{i}=1,2, \ldots \mathrm{m}$ dan $\mathrm{j}=1,2, \ldots \mathrm{n}$.

2. Memberikan nilai bobot ( $\mathrm{W}$ ) sesuai dengan tingkat kepentingan..

3. Melakukan normalisasi matriks dengan cara menghitung nilai rating kinerja ternormalisasi (rij) dari alternatif $\mathrm{Ai}$ pada atribut $(\mathrm{Cj})$ berdasarkan persamaan yang disesuaikan dengan jenis atribut (atribut keuntungan/benefit = MAKSIMUM atau atribut biaya/cost = MINIMUM). Apabila berupa artibut keuntungan maka nilai crisp (Xij) dari setiap kolom atribut dibagi dengan nilai crisp Maks (Maks Xij) dari tiap kolom, sedangkan untuk atribut biaya, nilai crisp Min (Min Xij) dari tiap kolom

\section{JURSIMA}

Jurnal Sistem Informasi dan Manajemen atribut dibagi dengan nilai crisp (Xij)setiap kolom.

4. Melakukan proses perankingan dengan cara mengalikan matriks ternormalisasi (R) dengan nilai bobot (W).

5. Menentukan nilai preferensi untuk setiap alternatif (Vi) dengan cara menjumlahkan hasil kali antara matriks ternormalisasi (R) dengan nilai bobot (W). Nilai Vi yang lebih besar mengindikasikan bahwa alternatif $\mathrm{Ai}$ lebih terpilih.

\section{Simple Additive Weighting (SAW)}

Metode SAW adalah Salah satu metode yang digunakan untuk menyelesaikan masalah dari Fuzzy Multiple Attribute Decision Making (FMADM). Metode Simple Additive Weighting (SAW) sering juga dikenal istilah metode penjumlahan terbobot. Konsep dasar metode SAW adalah mencari penjumlahan terbobot dari rating kinerja pada setiap alternatif pada semua atribut. Metode SAW membutuhkan proses normalisasi matriks keputusan (X) ke suatu skala yang dapat diperbandingkan dengan semua rating alternatif yang ada.

Menurut Henry (2009) adapun langkahlangkah dalam metode SAW adalah sebagai berikut:

1. Menentukan kriteria-kriteria yang akan dijadikan acuan dalam pengambilan keputusan, yaitu $\mathrm{C}$.

2. Menentukan rating kecocokan setiap alternatif pada setiap kriteria.

3. Membuat matriks keputusan berdasarkan kriteria (C), kemudian melakukan normalisasi matriks berdasarkan persamaan yang disesuaikan dengan jenis atribut (atribut keuntungan ataupun atribut biaya)

https://ejournal.giciku.ac.id/ STMIK GICI 
ISSN 2338-1523

E-ISSN 2541-576X

Volume 6 No. 1

Mei 2018

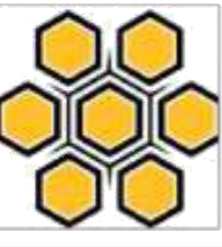

sehingga diperoleh matriks ternormalisasi R.

4. Hasil akhir diperoleh dari proses perankingan yaitu penjumlahan dari perkalian matriks ternormalisasi $R$ dengan vektor bobot sehingga diperoleh nilai terbesar yang dipilih sebagai alternatif terbaik (A) sebagai solusi

Normalisasi Matrix:

$r_{i j}=\left\{\begin{array}{c}\frac{X_{i j}}{\operatorname{Max}_{i} X_{i j}} \\ \frac{\operatorname{Min}_{i} X_{i j}}{X_{i j}}\end{array}\right\} \begin{gathered}\text { Jika } j: \text { atribut keuntungan (benefit) } \\ \text { Jika } j: \text { atribut biaya (cost) }\end{gathered}$

Dimana:

a. $\mathrm{r}_{\mathrm{ij}}=$ rating kinerja ternormalisasi dari alternatif $\mathrm{A}_{\mathrm{i}}(\mathrm{i}=, 2, \ldots, \mathrm{m})$

b. $\operatorname{Max}_{\mathrm{i}}=$ nilai maksimum dari setiap baris dan kolom.

c. $\operatorname{Min}_{\mathrm{i}}=$ nilai minimum dari setiap baris dan kolom.

d. $\mathrm{x}_{\mathrm{ij}}=$ baris dan kolom dari matriks.

Menghitung nilai preferensi:

$V i=\sum_{j=1}^{n} w_{j} r_{i j}$

Dimana:

a. $\mathrm{Vi}=$ Nilai akhir dari alternatif

b. $\mathrm{Wj}=$ Bobot yang telah ditentukan

c. $\quad$ rij $=$ Normalisasi matriks

d. Nilai Vi yang lebih besar mengindikasikan bahwa alternatif $\mathrm{Ai}$ lebih terpilih.

\section{Kelebihan Metode SAW}

Kelebihan dari model Simple Additive Weighting (SAW) terletak pada kemampuannya untuk melakukan penilaian secara lebih tepat berdasarkan bobot kriteria dan nilai preferensi.

Menurut Sri Eniyati (2011), metode SAW dapat menentukan nilai bobot untuk setiap atribut, kemudian dilanjutkan dengan proses perangkingan yang akan menyeleksi aternatif terbaik dari sejumlah alternatif terbaik. Selain itu, kelebihan dari model SAW dibandingkan dengan model pengambilan keputusan yang lain terletak pada kemampuannya untuk melakukan penilaian secara lebih tepat karena didasarkan pada nilai kriteria dan bobot prefensi yang sudah ditentukan. Henry Wibowo S (2009) menyatakan bahwa total perubahan nilai yang dihasilkan oleh metode SAW lebih banyak sehingga metode SAW sangat relevan untuk menyelesaikan masalah pengambilan keputusan.

\section{Kerangka Kerja}

Agar penelitian yang dilakukan dapat terlaksana dengan terstruktur dan jelas maka digambarkan langkah-langkah yang mencakup tahapan mulai dari awal hingga akhir selama penelitian. Adapun langkahlangkah tersebut tertuang ke dalam bentuk kerangka kerja sebagai berikut:
JURSIMA

Jurnal Sistem Informasi dan Manajemen https://ejournal.giciku.ac.id/

STMIK GICI 
ISSN 2338-1523

E-ISSN 2541-576X

Volume 6 No. 1

Mei 2018

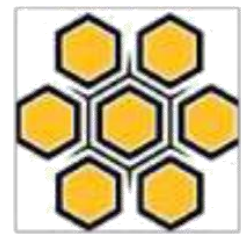

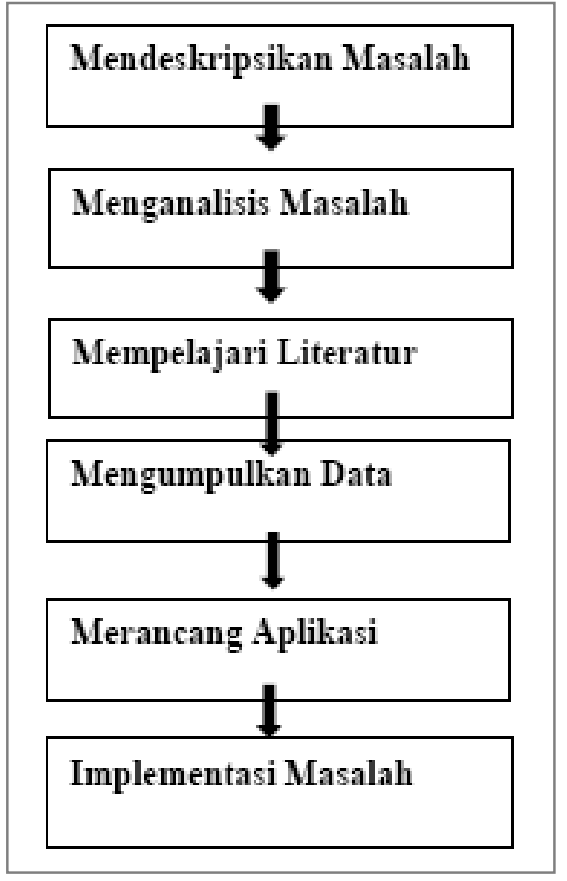

Gambar 1. Kerangka Kerja

\section{HASIL DAN PEMBAHASAN}

\section{Analisis Decision Support System dalam Angkat Kredit}

Penentuan konsumen kredit pada PT. OTO Finance Batam berdasarkan pada penilaian Credit Analyst, yaitu kepribadian pemohon kredit, kemampuan membayar pemohon kredit dan kondisi ekonomi pemohon kredit. Oleh karena itu, dalam penelitian ini akan menggunakan kriteria penentuan pemberian kredit yang digunakan oleh bank, yaitu Character (kepribadian), Capital (uang muka), Capacity (kemampuan), Collateral (jaminan), dan Condition (kondisi). Dengan menambah Collateral dan Capital diharapkan dapat memperkuat keputusan yang diambil.

JURSIMA

Jurnal Sistem Informasi dan Manajemen

\section{Pemberian Bobot Per Kriteria}

Langkah awal metode Simple Additive Weighting adalah pemberian nilai bobot di setiap kriteria pemohon kredit yaitu: character (kepribadian), capital (uang muka), capacity (kemampuan), collateral (jaminan), condition (kondisi). Lima kriteria tersebut dapat dibuat tabel sebagai berikut:

Tabel 1. Pemberian Bobot Kriteria

\begin{tabular}{|c|c|c|}
\hline Kode & Nama Kriteria & Bobot \\
\hline C1 & Character (Kepribadian) & 0,25 \\
\hline C2 & Capital(Uang Muka) & 0,1 \\
\hline C3 & Capacity (Kemampuan) & 0,45 \\
\hline C4 & Collateral (Jaminan) & 0,1 \\
\hline C5 & Condition (Kondisi) & 0,1 \\
\hline \multicolumn{2}{|c|}{ Total } & 1 \\
\hline
\end{tabular}

\section{Pemberian Nilai Crisp pada Tiap Kriteria}

Berdasarkan kriteria tersebut dibuat suatu tingkatan kriteria berdasarkan alternatif (pemohon kredit) yang telah ditentukan ke dalam nilai crisp. Rating kecocokan setiap alternatif pada setiap kriteria adalah sebagai berikut:

Tabel 2. Nilai Crisp Character/ Karakter

\begin{tabular}{|l|l|l|}
\hline Kriteria & Kriteria Pemohon & Nilai \\
\hline \multirow{4}{*}{$\begin{array}{l}\text { Character } \\
\text { / Karakter }\end{array}$} & Sangat Kurang & 0,2 \\
\cline { 2 - 3 } & Kurang & 0,4 \\
\cline { 2 - 3 } & Cukup & 0,6 \\
\cline { 2 - 3 } & Baik & 0,8 \\
\cline { 2 - 3 } & Sangat Baik & 1 \\
\hline
\end{tabular}

Tabel 3. Nilai Crisp Capital/ Uang Muka

\begin{tabular}{|c|l|l|}
\hline Kriteria & Kriteria Pemohon & Nilai \\
\hline Capital/ & DP $<15 \%$ & 0,2 \\
\cline { 2 - 3 } Uang & DP $16 \%-20 \%$ & 0,4 \\
\hline
\end{tabular}

https://ejournal.giciku.ac.id/ STMIK GICI 
ISSN 2338-1523

E-ISSN 2541-576X

Volume 6 No. 1

Mei 2018

\section{Muka}

\begin{tabular}{|l|l|}
\hline DP 21\%-25\% & 0,6 \\
\hline DP 26\%-30\% & 0,8 \\
\hline DP $>30 \%$ & 1 \\
\hline
\end{tabular}

\begin{tabular}{|l|l|l|}
\hline & Cukup & 0,6 \\
\cline { 2 - 3 } & Baik & 0,8 \\
\cline { 2 - 3 } & Sangat Baik & 1 \\
\hline
\end{tabular}

Tabel 4. Nilai Crisp Capacity/ Kemampuan

\begin{tabular}{|l|l|l|}
\hline Kriteria & Selisih & Nilai \\
\hline \multirow{4}{*}{$\begin{array}{c}\text { Capacity/ } \\
\text { Kemampu } \\
\text { an }\end{array}$} & $<500.000$ & 0,2 \\
\cline { 2 - 3 } & $500.001-1.500 .000$ & 0,4 \\
\cline { 2 - 3 } & $1.500 .001-2.500 .000$ & 0,6 \\
\cline { 2 - 3 } & $2.500 .01-3.000 .000$ & 0,8 \\
\cline { 2 - 3 } & $>3.000 .000$ & 1 \\
\hline
\end{tabular}

Dalam menentukan kriteria Capacity/ Kemampuan dapat dilakukan dengan rumus:

Selisih $=\sum$ Pendapatan $-\sum$ Pengeluaran

Adapun besarnya pengeluaran biaya hidup yang telah ditetapkan oleh OTO Finance Batam adalah sebagai berikut:

Tabel 5. Biaya Hidup

\begin{tabular}{|l|l|}
\hline \multicolumn{1}{|c|}{ Pemohon } & \multicolumn{1}{c|}{ Biaya Hidup } \\
\hline Lajang & 1.650 .000 \\
\hline Menikah & 2.300 .000 \\
\hline Anak 1 & 600.000 \\
\hline
\end{tabular}

Tabel 6. Nilai Crisp Collateral/ Jaminan

\begin{tabular}{|l|l|l|}
\hline Kriteria & Kriteria Pemohon & Nilai \\
\hline Collateral & Tidak ada penjamin & 0,5 \\
\cline { 2 - 3 } / Jaminan & Ada Penjamin & 1 \\
\hline
\end{tabular}

Tabel 7. Nilai Crisp Condition/ Kondisi

\begin{tabular}{|l|l|l|}
\hline Kriteria & Kriteria Pemohon & Nilai \\
\hline Condition & Sangat Kurang & 0,2 \\
\cline { 2 - 3 } / Kondisi & Kurang & 0,4 \\
\hline
\end{tabular}

JURSIMA

Jurnal Sistem Informasi dan Manajemen

\section{Pengujian Terhadap Sampel}

Penjabaran Alternatif Pada Setiap Kriteria Berdasarkan kriteria dan rating kecocokan setiap alternatif pada setiap kriteria yang telah ditentukan, selanjutnya penjabaran alternatif setiap kriteria yang telah dikonversikan dengan nilai Crisp.

Berikut perhitungan berdasarkan contoh kasus. Diambil sampel Pemohon Kredit dengan nama "Budi", dengan data sebagai berikut:

Tabel 8. Data Calon Pemohon Kredit

\begin{tabular}{|c|c|c|c|}
\hline \multirow[b]{2}{*}{ Kriteria } & \multicolumn{3}{|c|}{ Alternatif } \\
\hline & $\begin{array}{l}\text { Kriteria } \\
\text { Macet }\end{array}$ & $\begin{array}{l}\text { Budi } \\
\text { (Pemohon) }\end{array}$ & $\begin{array}{l}\text { Kriteria } \\
\text { Lancar }\end{array}$ \\
\hline $\mathrm{C} 1$ & Baik & Baik & $\begin{array}{l}\text { Sangat } \\
\text { Baik }\end{array}$ \\
\hline $\mathrm{C} 2$ & $\begin{array}{l}\text { DP } \\
<15 \% \\
\end{array}$ & $\begin{array}{ll}\text { DP } & 16- \\
20 \% & \\
\end{array}$ & $\mathrm{DP}>30 \%$ \\
\hline $\mathrm{C} 3$ & Cukup & Cukup & $\begin{array}{l}\text { Sangat } \\
\text { Baik }\end{array}$ \\
\hline $\mathrm{C} 4$ & $\begin{array}{l}\text { Tidak } \\
\text { Ada } \\
\text { Penjamin }\end{array}$ & $\begin{array}{l}\text { Tidak Ada } \\
\text { Penjamin }\end{array}$ & $\begin{array}{l}\text { Ada } \\
\text { Penjamin }\end{array}$ \\
\hline $\mathrm{C5}$ & Kurang & $\begin{array}{l}\text { Sangat } \\
\text { Baik }\end{array}$ & $\begin{array}{l}\text { Sangat } \\
\text { Baik }\end{array}$ \\
\hline
\end{tabular}

Diambil 2 kriteria, yaitu kriteria kredit macet dan kriteria kredit lancar. Dua titik tersebut digunakan untuk perbandingan skor "Budi". Berdasarkan data di atas, dibentuk

https://ejournal.giciku.ac.id/ STMIK GICI 
ISSN 2338-1523

E-ISSN 2541-576X

Volume 6 No. 1

Mei 2018

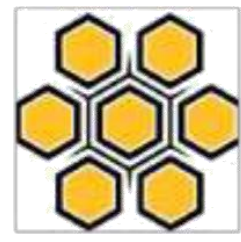

matriks keputusan dengan label $[\mathrm{X}]$ yang dikonversikan dengan nilai Crisp, seperti tabel berikut:

Tabel 9. Nilai Crisp Pemohon Kredit

\begin{tabular}{|c|l|l|l|l|l|}
\hline \multirow{2}{*}{ Kriteria } & \multicolumn{5}{|c|}{ Kriteria } \\
\cline { 2 - 6 } & C1 & C2 & C3 & C4 & C5 \\
\hline Macet & 0,6 & 0,2 & 0,6 & 0,5 & 0,4 \\
\hline Budi & 0,8 & 0,4 & 0,6 & 0,5 & 1 \\
\hline Lancar & 1 & 1 & 1 & 1 & 1 \\
\hline
\end{tabular}

Selanjutnya dilakukan normalisasi matriks dengan cara menghitung nilai rating kinerja ternormalisasi $\left(\mathrm{r}_{\mathrm{ij}}\right)$ dari altenatif $\mathrm{A}_{\mathrm{i}}$ pada atribut $\mathrm{C}_{\mathrm{j}}$ berdasarkan persamaan yang disesuaikan dengan jenis atribut (atribut keuntungan/benefit $=$ Maksimum atau atribut biaya $/$ cost $=$ Minimum). Apabila berupa atribut keuntungan maka nilai Crisp $\left(\mathrm{X}_{\mathrm{ij}}\right)$ dari setiap kolom atribut dibagi dengan nilai Crisp Max (Max $\mathrm{X}_{\mathrm{ij}}$ ) dari tiap kolom, sedangkan untuk atribut biaya nilai Crisp $\operatorname{Min}\left(\mathrm{X}_{\mathrm{ij}}\right)$ dibagi dengan nilai dari tiap kolom.

Adapun yang menjadi kriteria atribut benefit/keuntungan dalam penelitian ini adalah:

1. Character/karakter

2. Capital/Uang Muka

3. Capacity/Kemampuan

4. Collateral/Jaminan

5. Condition/Kondisi

Ini berarti kelima atribut yang menjadi kriteria adalah atribut keuntungan/benefit dan tidak ada satupun atribut biaya/cost sehingga kelima atribut dihitung dengan menggunakan rumus:

$$
r_{i j}=\left\{\frac{X_{i j}}{\operatorname{Max}_{i} X_{i j}}\right\}
$$

JURSIMA

Jurnal Sistem Informasi dan Manajemen

$$
r_{11}=\frac{0,6}{\operatorname{Max}(0,6 ; 0,8 ; 1)}=\frac{0,6}{1}=0,6
$$$$
r_{21}=\frac{0,8}{\operatorname{Max}(0,8 ; 0,8 ; 0,1)}=\frac{0,8}{1}=0,8
$$$$
r_{31}=\frac{1}{\operatorname{Max}(0,8 ; 0,8 ; 1)}=\frac{1}{1}=1
$$$$
r_{12}=\frac{0,2}{\operatorname{Max}(0,2 ; 0,4 ; 1)}=\frac{0,2}{1}=0,2
$$

$$
r_{22}=\frac{0,4}{\operatorname{Max}(0,2 ; 0,4 ; 1)}=\frac{0,4}{1}=0,4
$$$$
r_{32}=\frac{1}{\operatorname{Max}(0,2 ; 0,4 ; 1)}=\frac{1}{1}=1
$$$$
r_{13}=\frac{0,6}{\operatorname{Max}(0,6 ; 0,6 ; 1)}=\frac{0,6}{1}=0,6
$$$$
r_{23}=\frac{0,6}{\operatorname{Max}(0,6 ; 0,6 ; 1)}=\frac{0,6}{1}=0,6
$$$$
r_{33}=\frac{1}{\operatorname{Max}(0,6 ; 0,6 ; 1)}=\frac{1}{1}=1
$$

$$
r_{14}=\frac{1}{\operatorname{Max}(0,5 ; 0,5 ; 1)}=\frac{0,5}{1}=0,5
$$$$
r_{24}=\frac{0,5}{\operatorname{Max}(0,5 ; 0,5 ; 1)}=\frac{0,5}{1}=0,5
$$$$
r_{34}=\frac{1}{\operatorname{Max}(0,5 ; 0,5 ; 1)}=\frac{1}{1}=1
$$

$$
r_{15}=\frac{0,4}{\operatorname{Max}(0,6 ; 1 ; 1)}=\frac{0,4}{1}=0,4
$$


ISSN 2338-1523

E-ISSN 2541-576X

Volume 6 No. 1

Mei 2018

$r_{25}=\frac{1}{\operatorname{Max}(0,4 ; 1 ; 1)}=\frac{1}{1}=1$

$r_{35}=\frac{1}{\operatorname{Max}(0,4 ; 1 ; 1)}=\frac{1}{1}=1$

$$
\begin{aligned}
V_{3}= & (1 * 0,25)+(1 * 0,1)+(1 * 0,45)+ \\
& (1 * 0,1)+(1 * 0,1) \\
& =0,25+0,1+0,45+0,1+0,1 \\
& =1
\end{aligned}
$$

Selanjutnya dibentuk matriks sesuai dengan hasil yang didapatkan dari perhitungan tersebut.

$r=\left|\begin{array}{ccccc}0,6 & 0,2 & 0,6 & 0,5 & 0,4 \\ 0,8 & 0,4 & 0,6 & 0,5 & 1 \\ 1 & 1 & 1 & 1 & 1\end{array}\right|$

Langkah selanjutnya adalah dengan menentukan nilai preferensi untuk setiap alternatif (Vi) dengan cara menjumlahkan hasil kali antara matriks ternormalisasi (r) dengan vektor bobot berikut:

$[\mathrm{W}]=\{0,25 ; 0,1 ; 0,45 ; 0,1 ; 0,1\}$

Dengan menggunakan rumus:

$$
\begin{aligned}
V i= & \sum_{j=1}^{n} w_{j} r_{i j} \\
V_{1}= & (0,8 * 0,25)+(0,2 * 0,1)+ \\
& (0,6 * 0,45)+(0,5 * 0,1)+ \\
& (0,4 * 0,1) \\
= & 0,2+0,02+0,27+0,05+0,04 \\
= & 0,58 \\
& \\
V_{2}= & (0,8 * 0,25)+(0,4 * 0,1)+ \\
& (0,6 * 0,45)+(0,5 * 0,1)+(1 * 0,1) \\
= & 0,2+0,04+0,27+0,05+0,1 \\
= & 0,66
\end{aligned}
$$

\section{JURSIMA}

Jurnal Sistem Informasi dan Manajemen
Berdasarkan perhitungan tersebut, dapat diambil kesimpulan bahwa nilai $\mathrm{V}_{1}$ merupakan nilai dimana maksimum kredit macet mungkin terjadi dan V3 merupakan nilai maksimum dimana kredit berjalan lancar. Oleh karena itu, nilai kelayakan kredit berada di atas angka $\mathrm{V}_{1}$ dan di bawah atau sama dengan $\mathrm{V}_{3}$. Dalam kasus ini, Pemohon dinyatakan layak menerima kredit karena nilainya berada di atas nilai dari $\mathrm{V}_{1}$ yaitu sebesar 0,66 atau $66 \%$.

\section{IMPLEMENTASI}

Implementasi sistem dilakukan setelah tahap analisis dan pembahasan telah dilakukan. https://ejournal.giciku.ac.id/ STMIK GICI 
ISSN 2338-1523

E-ISSN 2541-576X

Volume 6 No. 1

Mei 2018

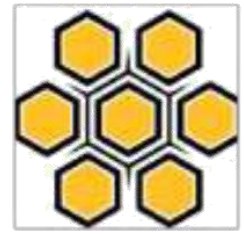

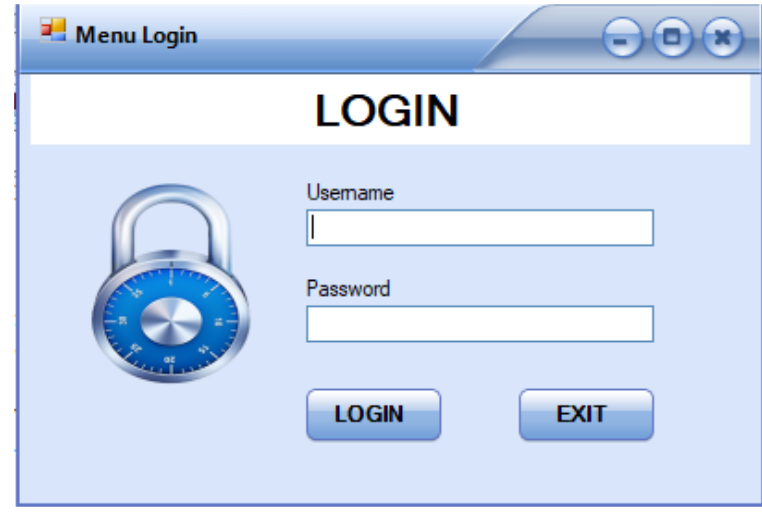

Gambar 2. Form Login

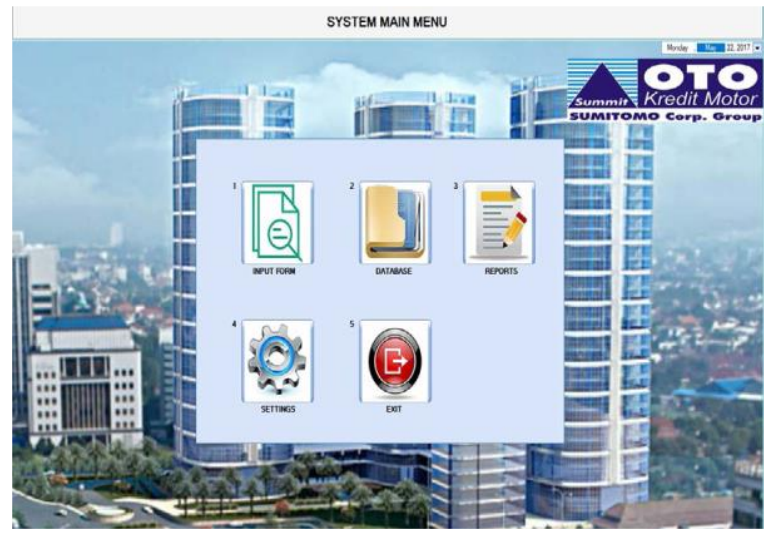

Gambar 3. Menu Utama

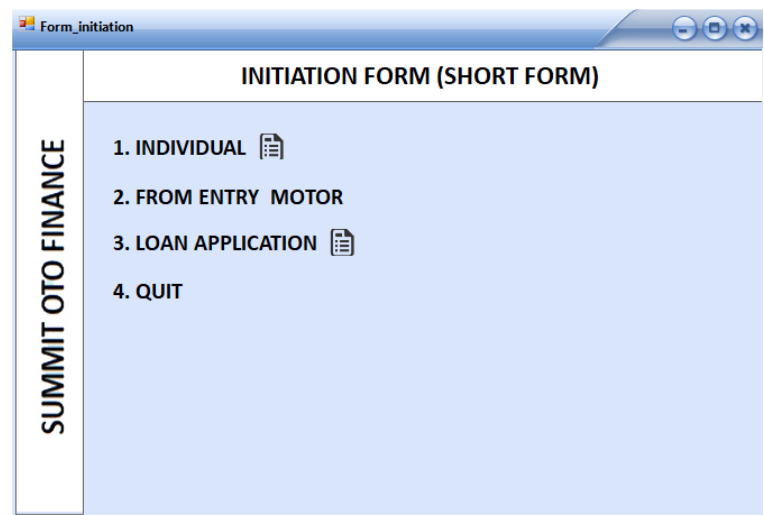

Gambar 4. Menu Input Data

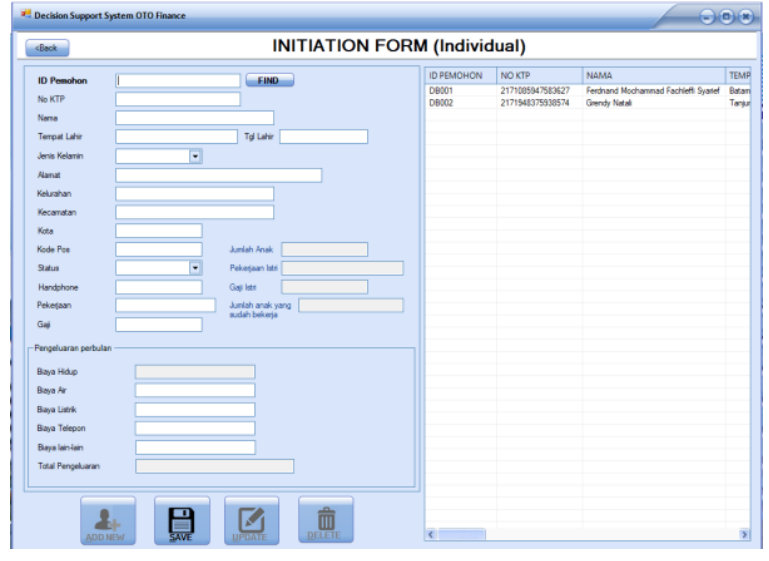

Gambar 5. Form Input Data Pemohon

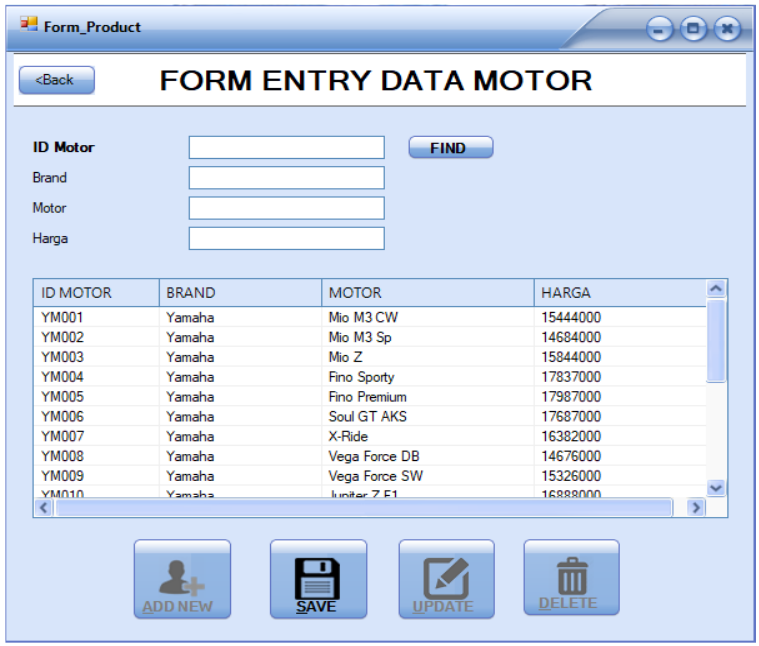

Gambar 6. Form Entry Data Motor
JURSIMA

Jurnal Sistem Informasi dan Manajemen https://ejournal.giciku.ac.id/ STMIK GICI 
ISSN 2338-1523

E-ISSN 2541-576X

Volume 6 No. 1

Mei 2018

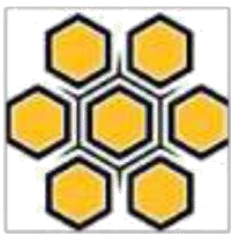

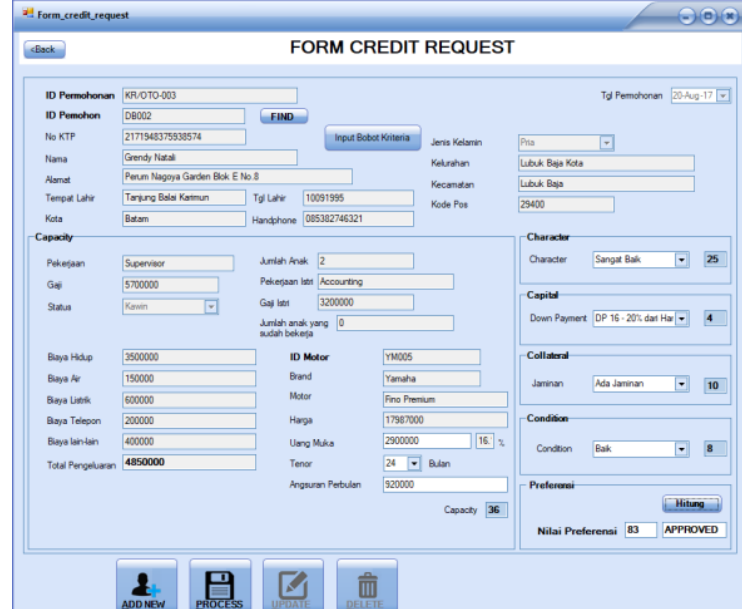

Gambar 7. Form Permohonan Kredit

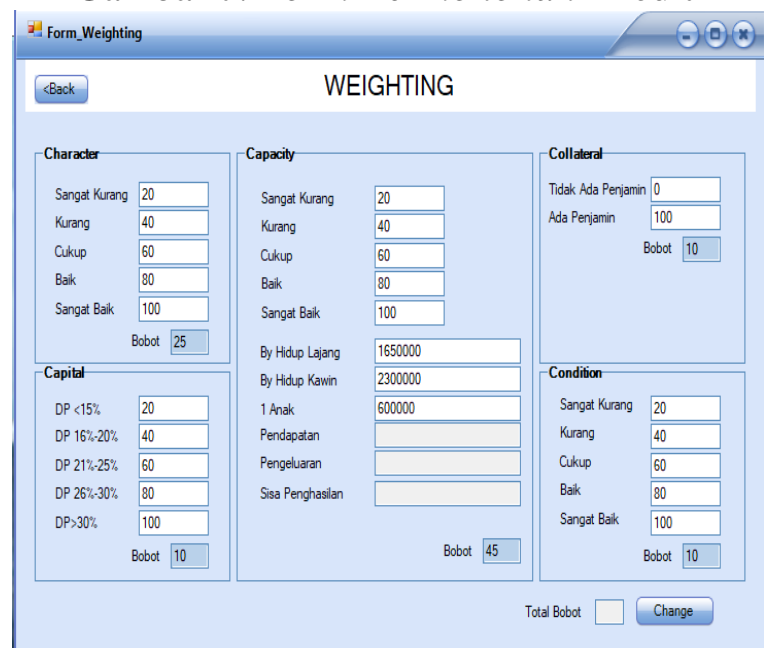

Gambar 8. Form Bobot Kriteria

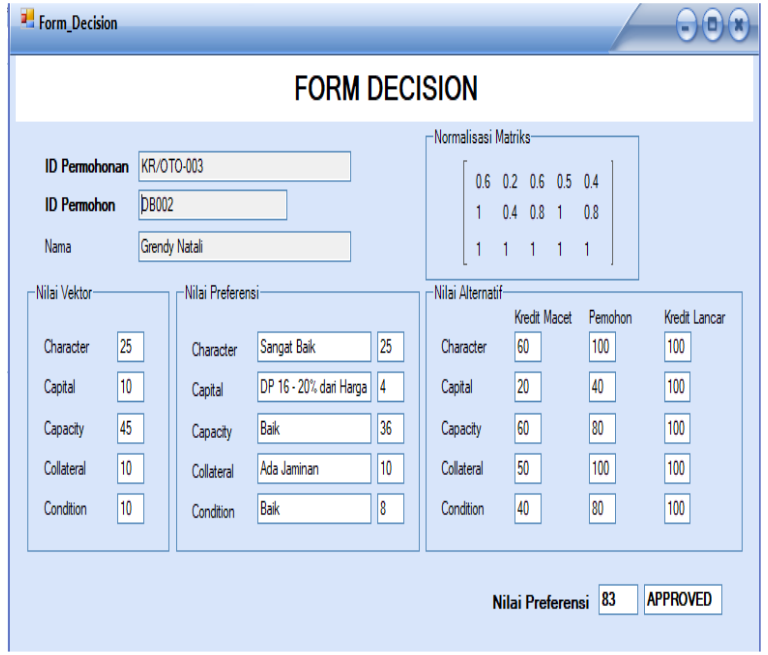

Gambar 9. Form Hasil Perhitungan

\section{KESIMPULAN}

Berdasarkan pembahasan yang sudah dilakukan, maka dapat diambil beberapa kesimpulan dari penelitian ini yaitu:

1. Penggunaan metode perangkingan SAW (Simple Additive Weighting) untuk menentukan kelayakan pemberian kredit motor pada OTO Finance Batam berdasarkan kriteria yang ditentukan. Adapun kriteria yang digunakan antara lain character (karakter), capital (uang muka), capacity (kemampuan), collateral (jaminan), condition (kondisi).

2. Antar muka (interface) sistem pendukung keputusan untuk menentukan kelayakan pemberian kredit bersifat userfriendly sehingga pengguna dapat menggunakannya dengan mudah.

3. Dengan adanya sistem pendukung keputusan untuk menentukan kelayakan pemberian kredit motor pada OTO Finance Batam dapat membantu dalam memberikan rekomendasi dan pertimbangan dalam pengambilan 
ISSN 2338-1523

E-ISSN 2541-576X

Volume 6 No. 1

Mei 2018

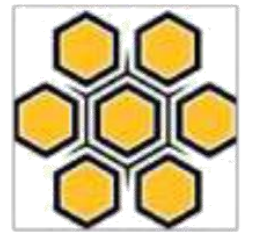

keputusan realisasi kredit berdasarkan kriteria yang telah ditentukan oleh pihak perusahaan.

\section{UCAPAN TERIMA KASIH}

Pada kesempatan ini, peneliti mengucapkan syukur kepada Allah atas terselesaikannya penelitian ini dan juga menyampaikan terima kasih yang sebesar-besarnya kepada semua pihak yang telah membantu dalam menyelesaikan penelitian ini baik yang terlibat secara langsung ataupun yang tidak.

\section{DAFTAR PUSTAKA}

Eniyati, Sri. 2011. Perancangan Sistem Pendukung Pengambilan Keputusan untuk Penerimaan Beasiswa dengan Metode SAW (Simple Additive Weighting). Jurnal Teknologi Informasi DINAMIK. Vol. 16(2).

Henry, W.S., dkk. 2009. Sistem Pendukung Keputusan untuk menentukan Penerimaan Beasiswa Bank BRI menggunakan FMADM (Studi Kasus: Mahasiswa Fakultas Teknologi Industri Universitas Islam. Seminar Nasional Aplikasi Teknologi Informasi 2009 (SNATI 2009).

Jogiyanto. 2009. Analisis dan Desain Sistem Informasi. Yogyakarta: Andi.

Romney, Marshall B., dan Paul John Steinbart. 2015. Accounting Information System. 13th ed. England: Pearson Educational Limited.

JURSIMA

Jurnal Sistem Informasi dan Manajemen
Turban, E. A., Aronson, J. E. dan Liang, T. P. 2011. Decision Support System and Intelligence System 7th Edition. Prentice Education International.

Vercellis, Carlo. 2009. Business Intelligence: Data Mining and Optimization for Decision Making. United Kingdom: John Willey \& Son. 